\title{
RELIGIOUS HARMONY WITHIN AHMADIYAH COMMUNITY: \\ (Study of Living Qur'an and the Peace Construction in the Village of Gondrong Kenanga
}

\author{
Adrika Fithrotul Aini) ${ }^{1}$ \\ STAI Sunan Pandanaran Yogyakarta \\ Email: adrikavenny@gmail.com
}

\begin{abstract}
In the midst of intolerant attitudes toward Ahmadiyah, the community of Ahmadiyah in Gondrong Kenanga present as a villagers that value diversity. Not only Ahmadiyah followers but also many other groups live in the village, such as Muslims affiliated to NU, Muhammadiyah, and other groups of religious believers. Interstingly, in everyday life they are able to protect themselve from getting involved in conflict and creating a peaceful and harmonious life. Harmony in the village Gondrong appears in at least two forms including in the pattern of inter-community relations in the environment and in daily life interction of people reflected in the social environment. Gondrong Ahmadiyah community is actively involved in various social activities that promote tolerance, cooperation, and solidarity. The work aims at getting the concept of peace in the Ahmadiyah community in Gondrong Kenanga. This study also examines the living Qur'an regarding the understanding of the concept of pluralism and harmony within Ahmadiyah members. This work is based on a field research project on the phenomenon of living Qur'an studies that examines the understanding of the Islamic teaching on diversity by the Jamaah Ahmadiyah Indonesia of Gondrong-kenanga (JAIG), and also the construction of peace which is practiced in their daily life.
\end{abstract}

Keywords: Peace Construction, Harmony, Living Qur'an, Ahmadiyah, Gondrong Kenanga.

\section{INTRODUCTION}

An adherent of a particular religion can usually take the attitude of its followers depending on the depth of their belief and religious understandings, whether are moderate, conservative, radical or liberal. A religious believer will say that the truth of a religion is absolute because it comes from God. The shifting of

${ }^{1}$ The author would also like to credit the Annual International Conference on Islamic Studies (AICIS) 2017 organized by the Ministry of Religious Affair of the Republic of Indonesia in which the author was invited to present the paper. It was held in Jakarta on 22-25 November 2017 
a truth claim begins when any religious revelation has been in contact with humans. The point is that the exoteric aspect of religion is separated from the esoteric aspect. ${ }^{2}$ In Islam, for example, the esoteric aspect is called as sufism, an ethical form coming from ihsan, while the exoteric comes up in a the form of aspects of human creation including science which can be recognized by everyone. Both forms of the mentioned aspects are as the results of cultural process that should be reinforced as a reflection of human servitude to God. The cultural process within a group of people practicing a religion is expected to adapt to the issues of diversity relations among the people. Therefor both objectivity and historicity are needed in the count of seeing them, not merely normativity, especially issues regarding the efforts to reinforce the construction of peace and harmony among religions.

Some of the statements above are a reflection of the phenomena occurring lately, in which a religious emotion, truth claim, a clash among religious communities, as well as political versus religious friction happen today in the globe, particularly in Indonesia in the case of this project. Thus, it is necessary to use a paradigm shift that is able to manage and maintain the peacebuilding that the community can run well. Peaceful construction efforts will further clarify that Islam provides resources for peace and Muslims are able to work with other groups to build peace. ${ }^{3}$ The idea of peacebuilding in Islam is to create the conditions in which life is without violence (nonviolence). Relations between religious groups are basically another form of human relationships. Social reality has proven that humans have influenced each other with specific values developing in certain area wherever they live. The values exist in the mindsets and patterns of human behavior (local wisdom). ${ }^{4}$ The values are obtained from a public understanding of the interpretation of the Qur'an. This perspective implies that members of religious groups in society are in a system of interaction that is integrated into a form of equilibrium. ${ }^{5}$ The role of religion shows its function when religion gives a change in the community and provides a new color in the community. Believing in the truth of a religion

${ }^{2}$ Frithjof Schuon, Mencari Titik Temu Agama-Agama, (Jakarta: Pustaka Firdaus, 2003), h.10. See also Abdullah Idi, Bangka: Social History Chinese Malay, (Yogyakarta: Tiara Discourse, 2011), p. 160

${ }^{3}$ Robert C.Johansen, "Radical Islam and Nonviolence: A Case Study of Religious Empowerment and Constraint Among Pashtune," Journal of Peace Research 34, no. 1 1997, p. 67.

${ }^{4}$ Local wisdom can be understood as local ideas that are thoughtful, full of wisdom, good-value, which is embedded and followed by members of the community. See the John M. Echol and Hasan Shadily, Kamus Inggris Indonesia (Jakarta: PT. Gramedia Pustaka Utama, 2003), p. 649.

${ }^{5}$ See in Nasikun, :Sistem Sosial Indonesia (Jakarta: PT. Rahagrafindo Persada, 1995), p. 9, and also in Thomas F. O'dea, Sosiologi Agama Suatu pengenalan Awal (Jakarta: PT. RajaGrafindo Persada, 1996), p. 3. 
would encourage people in the community as an essential element that will behave according to their doctrins. Of course this will affect the way of life and culture, which will be expressed in the conduct of life.

The phenomenon of living peacefully within the community of Ahmadiyah followers who live togther with other groups of religious believers in the village of Gondrong Kenanga Tangerang Banten in this aspect is interesting to be further explored. A couple of questions arrise; how religion is premised on a harmonious life and how construction efforts of peace which is based on understanding the verses of the Qur'an they practice in their daily lives? Gondrong Kenanga is not only inhabited by members of Ahmadiyah but also by other communities or groups of intra religious affiliation who live in peace together, such as those affiliated with Nahdlotul Ulama (NU), Muhammadiyah and Fron Pembela Islam (FPI). The Gondrong Ahmadiyyah community has the ability to establish Ukhuwah Basyariyah (brotherhood of human) within the society consiting of other groups of Muslim having different affiliation of organizational background.

Accordingly, this study focuses on religious beliefs that the people apply in their daily lives, which is called the living Qur'an, namely how the understanding towards religious verses within Ahmadiyah society in Gondrong (JAIG)? And how is the reaction and internalization of the understanding that is being implimented in their everyday lives? From understanding the verses of the Qur'an there is impact on the pluralism of social institutions in society which is one of the relevant media to strengthen the relationship among community groups. Their strong understanding are materialized in the construction of social integration, where integration is control towards conflicts and irregularities in a social system. ${ }^{6}$ Social integration is intended as a unification of the groups that were previously separated from each other through efforts to eliminate social differences. The process of integration through interpersonal communication and social contacts is an absolute requirement for integration. When social contact and communication between individuals occure, it will continue to respond to each other between groups. In view of the structural functional theory, there are two things that underlie the integration of a social system including an integrated community in the growing consensus among societal norms which are universal and fundamental and the one integrated because of the various members of the community as well as a member of various social unity (cross cutting loyalities). ${ }^{7}$

${ }^{6}$ Soerjono Soekanto, Beberapa Teori Sosiologi Tentang Struktur Masyarakat (Jakarta: Rajawali Press, 1983), p. 157.

${ }^{7}$ Nasikun, p. 69. 
Stephen K. Anderson (1993) ${ }^{8}$ explain that there are some important points with regards to integration theory. A community is a complex system which consists of parts which are interconnected and interdependent, and every part of each other significantly affects the other parts. Any part of a society exists because the part has an important function in maintaining the existence and stability of society as a whole. All people have a mechanism to integrate himself, ie a mechanism that can be taped together. One important part of this mechanism is the commitment of members of the public to a series of the same beliefs and values. People tend to lead to a unity equilibrium or homeostatis and disturbances and the other tends to cause adjustments in other parts in order to achieve harmony and stability. Social change is an unusual occurrence in the community but if it still happens then it will generally lead to consequences that benefit society as a whole. Those mentioned explanations make this study very interesting to elaborate what happen within people in Gondrong Kenanga.

\section{AHMADIYAH COMMUNITY IN GONDRONG KENANGA AT A GLANCE}

The Ahmadiyah community in Indonesia is divided into two, namely Qadian and Lahore. The Ahmadiyyah Qadian in Indonesia was brought by Muballigh Maulana Rahmat Ali as believed to be the envoy of Caliph II, Mirza Basyiruddin Mahmud Ahmad in 1925 in Banda Aceh. This information is adopted from the demand of the youth of West Sumatra who were conducting studies in Qadian. ${ }^{9}$ While the Lahore Ahmadiyyah came first brought by Maulana Ahmad and Mirza Wali Ahmad Baiq in 1924. ${ }^{10}$ From there, Ahmadyyah started to grow in Indonesia. The Ahmadiyyah group in Gondrong Kenanga, Tangerang, Banten started in 1946. H. Supena was to be believed as the founder. Then in 1948 Haji Sidiq was recognized as one of the leaders although his contribution is still in controversy. ${ }^{11}$ Ahmadiyah congregation did not get well attention from the public of Gondrong Kenanga. In the beginning was only a few people joined the congregation and became followers in 1950 under the leadership of H. Sidiq as for the Gondrong village Ahmadiyah community with Ahmadiyah Center located on the Rahmat Ali road, Cipondoh Tangerang, Banten. The community has grown up and today is lead by Margani. ${ }^{12}$

\footnotetext{
${ }^{8}$ Stephen K. Anderson, Sosiologi Makro: Sebuah Pendekatan terhadap Realitas Sosial, trans. Farid Wajidi, s. Menno (Jakarta: Rajawali Press, 1993), p. 9.

${ }^{9}$ Iskandar Zulkarnain, Gerakan Ahmadiyah di Indonesia, p. 312.

${ }^{10}$ Iskandar Zulkarnain, Gerakan Ahmadiyah di Indonesia, p. 180.

${ }^{11}$ Video of Ahmadiyah History in Gondrong, viewed on $23^{\text {rd }}$ May 2015.

${ }^{12}$ Interview section from Mr. Asep, $23^{\text {rd }}$ May 2015.
} 
Following the discourse of inter-religious relation in Indonesia with regards to Ahmadiyah, there was a case in 1989 that the Ahmadiyah community in Gondrong Kenanga suffered from massive resistance. The mosque they build was burned and there was a conflict between the followers of Ahmadiyah and other groups of people in the village who were not followers. The conflict remained there until in 1994 when the mosque was rebuilt. The case of conflict has become a starting point to rebuild better relationships among the different religilously aviliated groups living in the village. It is the case that today the people have better social interaction and the Ahmadiyah community live tothegether with others communities peacefully. The Ahmadiyah community continues to grow and develop some important public services and infrastructure such as the establishment of Ahmadiyah mosque, Maternal \& Child Health Centre (Posyandu), education instituions, branch offices, houses of mission, Ahmadiyah special funeral service, as well as Islamic education institutions (madrasah). The number of the Ahmadiyah members has significantly increased to more than 1008 people.

\section{LIVING QUR'AN AND THE HARMONY OF GONDRONG KENANGA SOCIETY}

The discussion of the forms of living Qur'an that is developed in the community is important with regards to the definition of living Quran explicitly. Living Qur'an can be interpreted as symptoms appearing in public in the form of patterns of behavior that comes from al-Qur'an. The pattern of behavior here is part of the responses of Muslims in their interactions with the verses of the Qur'an. Living Qur'an is a study or scientific research on a variety of social events associated with the presence of the Qur'an or the existence of the Qur'an in a particular Muslim community. ${ }^{13}$ The text of the Qur'an that lives in society which takes place sustainably, or the meaning and function of the real Qur'an, is understood and experienced by the Muslim community, where such understanding is to be the basis of society in carrying out their daily life. In the study of living Qur'an, there is a term that is used to parse reception of meaning. The Qur'an can not be separated from the history and civilization with a variety of events following the process of the revalation to the prophet Muhammad. The history of the revelation process the Quran gives a new empty space to think of relevant meaning in accordance to the conditions of the time of the revelation. This fact has been understood of why Qur'an is recepted by Muslims as an agent of culture. The reception is divided into three types namely hermeneutical, aesthetic and cultural. ${ }^{14}$

${ }^{13}$ M. Mansur, et all., Metodologi Penelitian Living Qur'an dan Living Hadis, (Yogyakarta: Teras, 2007), p. 8.

${ }^{14}$ Because, from this reception will occur new meaning that leads to that "piety". 
Hermeneutical reception is understood as an attempt to understand the content of the Qur'an that is mostly done with the interpretation of the verses of the Qur'an. ${ }^{15}$ The meaning generated by the hermeneutic process depends on certain aspects of the interpreters when doing the interpretation of text including experience and knowledge. The other important aspects are also the condition of the process of hermeneutical interpretation which is related to the influence of space and time. ${ }^{16}$ Aesthetic reception also proceeds from the reception of the Qur'an and is called the aesthetic reception because the scripture aesthetic reception is expressed for aesthetic purposes. ${ }^{17}$ In other words, the definition of aesthetic reception is the beauty of the language of the Qur'an thai is expressed in various forms. ${ }^{18}$ This will open up opportunities for the inclusion of other forms of text interpretation other than the meaning explanatory of the Qur'an. And the cultural reception is a reciprocal process in which the Qur'an is trying adapt to the cultural elements by the Muslims with regards to their socio-cultural facts. The Qur'an is interpreted as the meaning given by the people who will implement the teaching of the Qur'an in their daily lives. ${ }^{19}$ beyond textual condition.

There are several systems to be considered within the view of cultural values namely a system of idea, social systems and artefact systems. System of idea is a form of knowledge system that includes belief systems, value systems and ideal systems. Belief system is a supernatural form of belief and the human relationship with the form. While the value system is something that is appreciated; it is not just an act which is produced but also things that support any actions. The system of ideal is something desired. The social system is a pattern of behavior that makes up a community. And the artifact system is a form of material culture artifacts. Therefore, the reception of the Qur'an in the living Qur'an means a description of how a person receives and reacts to the Qur'an by receiving, responding to utilize or use it. The Qur'an is regarded as syntactic composition containing text or a manuscript, which has its own meaning or set of words that have loose particular meanings. ${ }^{20}$ From the living understanding of the Qur'an, the Ahmadiyah community in Gondrong

\footnotetext{
${ }^{15}$ Ahmad Baidhowi, "Resepsi Estetis al-Quran”, Esensia, VIII, Januari 2007, p. 19.

${ }^{16}$ Nyoman Kutha Ratna, Estetika sastra dan Budaya (Yogyakarta: Pustaka Pelajar, 2007), p. 2.

${ }^{17}$ Ahmad Baidhowi, "Resepsi Estetis al-Quran”, Esensia, Volume VIII, Januari 2007, p. 20.

${ }^{18} \mathrm{Ibid}$, p. 22.

${ }^{19}$ Heddy Shri Ahimsa-Putra, "The Living Al-Qur'an: Beberapa Perspektif Antropologi"Walisongo, Volume 20, Nomor 1, Mei 2012, p. 235.

${ }^{20}$ Ahmad Rafiq, "Sejarah al-Qur’an: Dari Pewahyuan ke Resepsi (Sebuah Pencarian Awal Metodologi)" in Sahiron Syamsuddin (ed.), Islam, Tradisi, dan Peradaban (Yogyakarta: Bina Mulia Press, 2012), p. 73.
} 
Kenanga internalize their understanding of verses of the Qur'an to realize the value of peace in a society based on verses of the Qur'an including Al-Baqarah 257. "There shall be no compulsion in [acceptance of] the religion. The right course has become clear from the wrong. So whoever disbelieves in Taghut and believes in Allah has grasped the most trustworthy handhold with no break in it. And Allah is Hearing and Knowing."

Based on the mentioned verse, the Ahmadiyyah community understands that the verse is a command not to force aomeone to believe in any religion. The community respects the other various religions. ${ }^{21}$ They also believe that the members should not impose the Ahmadiyah faith to others, to avoid any conflict. Although there is an order to sperad the faith, it should be without imposment, as the understanding that they hold from the Qur'an at An-Nahl 125. From the verse, it can be understood that it is required to convey the value of diversity. Wisdom is the key to confront the differences. Thus, the way to ensure peace is to run humility, justice, sincere, devout, and return to God in which a man will become a trully human. Sagheer, as being interviewed, give an explanation that faith is a human bussiness with his Lord, and you can not interfere in this matter. Everyone is welcome to live according to their faith and carries out their religious rituals. If there is a ritual practice in the name of religion that hurt others and against the law, then the legal power is to act, because the cruel ritual practices were never taught by any religion"22 A couple of verses of the Quran are used to support his argument for the realization of peace building; Al-Maidah 3 and 9: "And do not let the hatred of a people for having obstructed you from al-Masjid al-Haram lead you to transgress. And cooperate in righteousness and piety, but do not cooperate in sin and aggression. And fear Allah ; indeed, Allah is severe in penalty." "O you who have believed, be persistently standing firm for Allah, witnesses in justice, and do not let the hatred of a people prevent you from being just. Be just; that is nearer to ighteousness. And fear Allah; indeed, Allah is Acquainted with what you do."

The verse is understood as a clause for creating peace by people in Gondrong Kenongo. It is percieved as a command to act wisely and to allow reciprocal hostility among humans. ${ }^{23}$ Thus, in the community, although thet live with many differences they always foster a sense of peace as a human duty. This is what is called the hermeneutical reception in the living Quran. It gives an

\footnotetext{
${ }^{21}$ Interview section from Mr. Shaghir, tanggal 25th June 2015.

${ }^{22}$ Inteeview section from Mr.Shaghir, 25th Jun3 2015 and see in Abdul Bashit, Krisis Dunia dan Jalan Menuju Perdamaian (Jakarta: Neratja, 20 13).

${ }^{23}$ Ahmadiyah Community Team, al-Qur'an Terjemah dan Tafsir Singkat, terj. Dewan Naskah Jemaat Ahmadiyah (Jakarta: Neratja, 2014), p. 417.
} 
understanding to Ahmadiyah society concerning to establish peace in society. There is a prohibition to run away from. They take a lesson from the Prophet Muhammad who did not retaliate to those who had tortured him, but forgave them and allowed them to describe their faith they believe. ${ }^{24}$ According to an Ahmadyah member in Gondrong Kenongo, to achieve harmony people need to create some actions. People need the convenience of social interaction namely the creation of social harmony, human nature. Social empathy needs the awareness of social identity of each individual in increasing the actual empathy capacity. And people also need to add self-awareness (self-aware autonomy) and reduce the tendency of truth claims. ${ }^{25}$

The JAIG in Gondrong Kenongo try to do good to others based on the teaching of the mentioned verses although some people around them see them in negative views. The verse is also understood as the basis of sincerity and obedience in good deed. ${ }^{26}$ This is manifested in various social activities such as the humanitarian programs like donor programs. There are some JAIG residents who have been donating their eyes for later donated after death. While the aesthetic reception which can be seen in the creation of a harmonious society is the JAIG slogan of "Love for all, hatred for none". The slogan is internalized from the verses of the Qur'an that upholds the values of love rather than hatred. The slogan is a way to revive the Qur'an that would be no violence in religion. From the incident of Gondrong Kenanga conflict in 1989 the community take a serious standpoint to the principle that no more conflict should accour. They convey the message to all members in a variety of activities. As a result, up to now there has never been a conflict between them anymore. Harmony and mutual respect manifest in every individual within the community.

For cultural reception they believe that the religion of God is a grace. The community members should not get into conflicts due to the differences but find common understanding from the similarities that can strengthen peace. The understanding toward the Ahamadiyyah teaching has a meaningful value within JAIG members. This understanding makes JAIG members perpetuating the concept of peace and avaiding hatred among human beings as people should provide assistance and cooperation to each other. ${ }^{27}$ Finaly the JAIG community believes that can meet their dreams which is manifested in the values of peace throughout the world as God has commanded human beings

\footnotetext{
${ }^{24}$ See in explanation of Mirza Masroor Ahmad in Abdul Basit, Krisis Dunia Dan Jalam Menuju Perdamaian (t.tp: Neratja Press, 2014), p. 16.

${ }^{25}$ Interview section from Mr.Shaghir, 25th June 2015.

${ }^{26}$ Mrs. Mira's explanation, 23rd May 2015. She told: "We were trained since our childhood to do qurban and help human."

${ }^{27}$ Interview section from Mrs.Shaghir, 25th June 2015.
} 
to do so in the Qur'an.

\section{CONSTRUCTION OF PEACE IN GONDRONG AHMADIYAH}

Religious belief has a high degree of value in the minds of the Ahmadiyaah community. They believe that religion is a human expression to the God. Mohammad Iqbal (as quoted by M. Damami, 2002) explains that religion is an expression of the whole man and is therefore religion is a very valuable and precious. ${ }^{28}$ It is intersting to see how Gondrong Kenang community maintains and builds a balance of interaction within the different religious groups in Kenanga Village. Strong social cohesion of Ahmadiyah community is seen when they spread the awareness for the community of the importance of living in harmony and harmonious (guyub rukun). They have an understanding that religion has one function as a source of morality. The leader of the commmunity as known by the Caliph IV mentions the mentioned slogan as the foundation of th community to perform good deeds to other groups of people. A peace symposium held by the Caliph is based on the understanding of the Qur'an of Al-Maidah 3 and 9 that become the spirit of the life of the community. The internalization of the mentioned verses becomes the soul foundation of every Gondrong Ahmadiyah community member to always bring peace. In an interview Shaghir mentions that the Qur'an has provided some golden principles to create peace in the world. Conveying the message is one way toward the efforfs of building peace.

I need to provide the explaination of the factors that make Gondrong Kenanga community can reduce the the tension of intra religious conflicts or sentiments within the diversity of social dynamics. Some of the factors that support the peacebuilding within the community are the kinship or genetic relationship, social system, social activities that become public space for Gondrong community, the roles of the elite community or religious leaders in the village and governance structures that can create cohesion by producing peaceful policies for Gondrong communities. Those factors are highly influential in bridging the social activity or interaction that lead to solidarity and harmony in the society. Various activities and forms of solidarity affect the quality of the relationship among members of the group in the community. Below is the detail of the mentioned factors supporting the peacebuilding efforts within the community.

The kinship of the members of the community has proven to support their understanding of tolerance and encourage an inclusive attitude in their lives.

${ }^{28}$ Mohammad Damami, Makna Agama dalam Masyarakat Jawa, (Yogyakarta: LESFI, 2002), p. 2. 
Again, the Gondrong Kenanga village is not only inhabited by Ahmadiyah community but also by various group having different religious ideology backgrounds. Yet the people are in family ties. The strong family relationships can be seen from the statement of Maria as interviewed. Se said that people in Gondrong can live in harmony and peace although having different religious backgrounds, some of us are still Islam although having different affiliation of thought. What can unite us to always live in harmony is a family tie. My own family belongs to Ahmadiyah community and my enching is Nahdlotul Ulama (NU). We recpect each others and respect differences. ${ }^{29}$ Such kinship ties show the existence of interaction based on respectfullness to individual actions. ${ }^{30}$ Mutual respect between religious groups of Gondrong Kenanga villagers has become an important foundation in the social life. The Awareness to socialize the attitute to their fellow citizens supports the development of solidarity among the people of Gondrong Kenanga.

The people of Gondrong Kenanga also has a local practice to visit their family members. The practice has become apart of the culture of the people. They would visit to a neighbor's house and relatives no matter what belief they belong to (Ahmadiyah community members of other). This social interaction is a dynamic relationship which involves awareness of the importance of establishing social life in society. An NU leader mentions in an interview that people do have different belief here, but in relation to man (hablun min an-nas) we could not be separated. We may be different in terms of inter-intra religious group affiliation, but we understand that we need to build peace. Moreover we still have family relations. The Ahmadiyyah community often greet us with social activities. When they have a program such as Jalsah Salanah, we are also invited. I am proud to live in this village. We belong to different religious groups but harmonious. ${ }^{31}$

The social system is not only a collection of individuals, but also is a social act in which individuals interact with each other. The values of living together in a common enviroenment is very important. Working together with the village leaders (the govermnet), the Ahmadiyyah community innitiate social activities to provide a public space for interaction among people who belong to various inter-intra religious groups. The Ahmadiyah community comes with a name as the Jemaiat Ahmdiyah Gondrong (JAIG). They would welcome all villagers to the programmes they innitiate such as blood donor and health care for mothers and children. Not only to villagers, the JAIG would invite the

\footnotetext{
${ }^{29}$ Interview section from Mrs.Maria, tanggal 23 ${ }^{\text {rd, }}$ May 2015.

${ }^{30}$ George Ritzer, Sociology: A Multiple Paradigm Science, trans. Alimandan (Jakarta: CV. Rajawali, 1985), p. 60.

${ }^{31}$ Interview section from Figure of NU, 23 ${ }^{\text {rd }}$, May 2015.
} 
village government officials as they want to show their sincere openness to other groups. In this public sphere, dialogues within the Gondrong Kenanga community happens so that they understands the reality of the plurality of religious life in the village

In Indonesian government system, there is what is called as Pemerintahan Desa (village government) that consists of village government structure headed by Kepala Desa (the head of the village) and Village Consultative Body (BPD). BPD members consist of neighborhood leaders, professional groups, religious leaders, and smaller community leaders ${ }^{32}$ In the structure of village government, BPD can be considered as the parliament of the village. Both institutions are structurally an element of village administration. Village government is an institution that is close to people's lives. in this context the role of the village administration is very significant in maintaining order, harmony, harmony among the villagers as well as the coordination of existing social-religious institutions. Therefore, the relationship or society interaction should be built on conventional norms and formal legal, and the harmony of public relations can be assured in social life. ${ }^{33}$

Although the Kepala Desaeader does not belong to Ahmadiyah community, he welcome and respect Ahmadiyah community activities in the Gondrong Kenanga village. Sagheer mentions in is interview that when we have programmes we always invite Pemerintah Desa and the Kepala Desa always meets our invitation. Perhaps, it is one manifestation of sense of peace and tranquility between Ahmadis and non-Ahmadis. ${ }^{34}$ The Kepala Desa also support the Ahmadiyah activities. For example, there will be soup kitchen run by the Ahmadiyah members, and the village government provides fund to assist these activities. In addition, the members of the Gondrong Kenanga Ahmadiyyah community also get involved in handling the affairs of the village, for example those involved in regeneration in the village administration. The role of the elites have been very important to understand Ahmadiyah religious activities. The elites have functioned as the control of the community in terms of communication and dialogue that can foster tolerance and mutual respect in the village. The social control supports the effors of peacebuilding. ${ }^{35}$

\footnotetext{
Pasal 200

${ }^{33}$ Moh. Solekhan, Penyelenggara Pemerintahan Desa (Malang: Setara Press, 2012), p. 41.

${ }^{34}$ Interview section from Mrs.Shaghir, 25th June 2015.

${ }^{35}$ Jalaluddin Rakhmat, Psikologi Komunikasi (Bandung: Remaja Rosdakarya, 1996), p. 101.
}

${ }^{32}$ Indonesia, Undang-Undang Tentang Pemerintahan Daerah, No. 32 Tahun 2004, 


\section{CONCLUSION}

The concept of peace has become an inspiration of the Ahmadiyyah community life in fostering harmony in Gondrong Kenanga village. This is a phenomenon of living Qur'an based on the reception hermeneutical, aesthetic and cultural for fostering harmony and peace that the people understand based on the understanding of the verses of the Qur'an. The verses of the Qur'an as the basis of understanding of harmony, among others, include Al-Baqarah 256 and Al-Maidah 3 and 9. Based on their understanding of the verses of the Qur'an, the Gondrong Ahmadiyah community members establishe a pattern of interaction that aims to build a peaceful construction. Peace building construction of the Gondrong Kenanga Ahmadiyah community is manifested in several factors, namely in social activities, the role of the elite of village government, as well as family relationships between. Understanding of the Qur'an towards the concept of peace will strive to be done with a pattern of intense interaction between them. Public service activities have become a public space to provide emotional bonding between people which can lead to reduce destructive conflicts. Understanding of the Qur'an on peace is embodied in the slogan that became the principle, namely "Love For All, Hatred for None".

\section{BIBLIOGRAPHY}

Anderson, S. K. (1993). Sosiologi Makro: Sebuah Pendekatan terhadap Realitas Sosial, (translated into Indonesian by Farid Wajidi and S. Menno). Jakarta: Rajawali Press.

Baidhowi, A. (2007). Resepsi Estetis al-Qur'an, in Esensia, Volume VIII, Januari 2007.

Bashit, A. (2013). Krisis Dunia dan Jalan Menuju Perdamaian. Jakarta: Neratja,

Damami, M. (2002). Makna Agama dalam Masyarakat Jawa. Yogyakarta: LESFI.

Echol, J. M. \& Shadily, A. (2003). Kamus Inggris Indonesia. Jakarta: PT. Gramedia Pustaka Utama.

Idi, A. (2011). Bangka: Sejarah Sosial Cina Melayu. Yogyakarta: Tiara Wacana.

Indonesia, Undang-Undang Tentang Pemerintahan Daerah, No. 32 Tahun 2004, Pasal 200. 
Johansen, R. C. (1997). Radical Islam and Nonviolence: A Case Study of Religious Empowerment and Constraint Among Pashtune. in Journal of Peace Research 34, no. 11997.

Mansur, M. (at.al). 2007). Metodologi Penelitian Living Qur'an dan Living Hadis. Yogyakarta: Teras.

Nasikun, (1995). Sistem Sosial Indonesia. Jakarta: PT. Rahagrafindo Persada.

O’dea, T. F. (1996). Sosiologi Agama Suatu pengenalan Awal. Jakarta: PT. RajaGrafindo Persada.

Putra, H. S. A. (2012). The Living Al-Qur'an: Beberapa Perspektif Antropologi. Walisongo, Volume 20, Nomor 1, Mei 2012.

Rosyid, M. (2015). Mendialogkan Ahmadiyah: Belajar dari Cikeusik dan Kudus. Kudus: Neratja Press.

Ratna, N. K. (2007). Estetika sastra dan Budaya. Yogyakarta: Pustaka Pelajar.

Ritzer, G. (1985). Sociology: A Multiple Paradigm Science, (trnslated by. Alimandan). Jakarta: CV. Rajawali.

Schuon, F. (2003) Mencari Titik Temu Agama-Agama. Jakarta: Pustaka Firdaus.

Soekanto, S. (1983) Beberapa Teori Sosiologi Tentang Struktur Masyarakat. Jakarta: Rajawali Press.

Solekhan, M. (2012). Penyelenggara Pemerintahan Desa. Malang: Setara Press.

Syamsuddin, S. (ed.) (2012). Islam, Tradisi, dan Peradaban. Yogyakarta: Bina Mulia Press.

Tim Jemaat Ahmadiyah, (2014). al-Quran Terjemah dan Tafsir Singkat, (Translated by Dewan Naskah Jemaat Ahmadiyah). Jakarta: Neratja.

Zulkarnain, I. (2011). Gerakan Ahmadiyah di Indonesia. Yogyakarta: LkiS. 
